\section{Diagnostic validity of self-reported oral health outcomes in population surveys: literature review}

\section{Validade diagnóstica de agravos bucais autorreferidos em inquéritos populacionais: revisão da literatura}

\author{
Renato Quirino Ramos',"1 \\ João Luiz Bastos",III \\ Marco Aurélio Peres ${ }^{\text {II,III, IV }}$ \\ 'Undergraduate Course in Dentistry, Center of Health Sciences, Universidade \\ Federal de Santa Catarina - Florianópolis (SC), Brazil. \\ "Research group in Public Health Dentistry, Department of Public Health, \\ Center of Health Sciences, Universidade Federal de Santa Catarina - \\ Florianópolis (SC), Brazil. \\ I'Postgraduate Program in Collective Health, Center of Health Sciences, \\ Universidade Federal de Santa Catarina - Florianópolis (SC), Brazil.

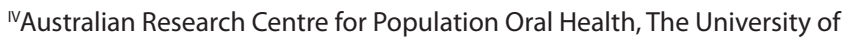 \\ Adelaide, Australia.
}

Correspondence: Marco Aurélio Peres. ARCPOH - The University of Adelaide - 122 Frome Street (Cnr Pirie Street) - Room 1.12, Level 1 - SA 5000 - Adelaide, Australia. E-mail: marco.peres@adelaide.edu.au Financing source: National Council for Scientific and Technological Development (CNPq), scientific initiation scholarship (RQR), process n. 508903/2010-6; Marco Aurélio Peres is a scholar on research productivity of CNPq.

Conflict of interests: nothing to declare.

\section{Abstract}

Population-based health surveys are increasingly including self-reported oral health measures. However, their validity is frequently questioned. This study aimed to review the diagnostic validity of selfreported oral health measures — regarding periodontal conditions, number of remaining teeth and use and need of prostheses and to present prototypes of oral health items to assess periodontal conditions. Papers published between 1991 and 2011 were identified through PubMed database. The sample profile, the sample size and the methods used in each study were analyzed, as well as the sensitivity, specificity, positive and negative predictive values of the oral health items. Periodontists were contacted, using a standardized text, sent by e-mail, which asked them to provide self-reported items regarding periodontal conditions. We reviewed 19 studies; 13 assessed periodontal conditions; five, the number of remaining teeth and four, the use and need of prosthesis - some studies evaluated two or more conditions simultaneously. Five of the eight periodontists suggested questions to assess periodontal conditions. The maximum and the minimum sensitivity values to assess periodontal conditions, number of remaining teeth and use and need of prosthesis were 100 and $2 \%$; 91 and $21 \%$; 100 and $100 \%$; respectively; the maximum and the minimum specificity values were 100 and 18\%; 97 and 96\%; 93 and $93 \%$; respectively. In conclusion, there are acceptable sensitivity and specificity values for number of remaining teeth and use and need of prosthesis only. Finally, we consider there is the need for further studies in the national context, in order to assess the impact of the questions about self-reported oral health conditions in epidemiological analyses. Therefore, it will be possible to empirically verify if self-reported questions can be used in such studies.

Keywords: Population surveys. Diagnostic self evaluation. Validity of tests. Tooth loss. Dental prosthesis. Periodontitis. 


\section{Resumo}

Inquéritos epidemiológicos têm incluído, cada vez mais, questões de saúde bucal autorreferidas. Entretanto, a validade de tais questões é frequentemente questionada. O objetivo deste estudo foi revisar a validade diagnóstica de questões sobre condições bucais autorreferidas - condições periodontais, número de dentes presentes e uso e necessidade de prótese dentária - e apresentar protótipos de questões autorreferidas para condições periodontais. Os artigos foram identificados na base PubMed, publicados no período entre 1991 e 2011. Foram descritos a composição, o tamanho da amostra e os métodos empregados em cada estudo, além da sensibilidade, especificidade, valor preditivo positivo e valor preditivo negativo das questões utilizadas. Foram contatados periodontistas, através de texto padronizado e enviado por correio eletrônico, solicitando propostas de itens sobre condições periodontais autorreferidas. $\mathrm{O}$ presente estudo revisou 19 trabalhos. Desses, 13 avaliaram condições periodontais; cinco avaliaram o número de dentes presentes; e quatro avaliaram o uso e a necessidade de prótese dentária - alguns estudos avaliaram duas ou mais condições simultaneamente. Cinco dos oito periodontistas contatados sugeriram perguntas para avaliar condições periodontais. A sensibilidade máxima emínima encontrada para condições periodontais, número de dentes presentes e uso e necessidade de prótese dentária foi de 100 e $2 \%$; 91 e $21 \%$; 100 e $100 \%$, respectivamente; a especificidade máxima e mínima foi de 100 e 18\%; 97 e 96\%; 93 e 93\%, respectivamente. Concluímos que existem valores de sensibilidade e especificidade aceitáveis somente para a aferição do número de dentes presentes e da necessidade de prótese. Entretanto, são necessários estudos, no contexto nacional, que avaliem o impacto de perguntas sobre as condições de saúde bucal autorreferidas, verificando se, empiricamente, questões autorreferidas podem ser utilizadas em tais estudos.

Palavras-chave: Inquéritos demográficos. Autoavaliação diagnóstica. Validade dos testes. Perda de Dente. Prótese dentária; Periodontite.

\section{Introduction}

Epidemiological broad scale surveys use self-reported questions to obtain information concerning the health of population groups. One example is the National Health Interview Survey (NHIS), performed since July, 1957, in the United States of America (USA) ${ }^{1,2}$. This research is the main source of information obtained by means of household interviews concerning the health of the population in the USA ${ }^{1,2}$. Another important population survey is the Behavioral Risk Factor Surveillance System (BRFSS), which, since 1984, monitors the health conditions and behaviors of the population in the USA by means of interviews by telephone $\mathrm{e}^{3-5}$. More recent studies, such as the South Africa Demographic and Health Survey (SADHS), whose second edition was performed between October 2003 and August 2004, and Vigilância de Fatores de Risco e Proteção para Doenças Crônicas por Inquérito Telefônico (VIGITEL), a study conducted annually in Brazil since 2006, have been using self-reported questions ${ }^{6,7}$.

This observation technique has also been used in specific oral health studies ${ }^{4,8}$, as in the case of the National Survey of Adult Oral Health (NSAOH) and the Adult Dental Health Survey (ADHS), conducted in Australia and in the United Kingdom, respectively ${ }^{9,10}$. Additionally, epidemiological surveys have been giving preference to the use of self-reported questions in comparison to clinical examinations as a way to produce information, thus including more questions related to oral health. One study reflecting such trend is Pesquisa Nacional de Saúde (National Health Research), a broad survey about health conditions to be conducted in Brazil in 2013, which will use selfreported items for data production ${ }^{11}$.

The method recognized as gold-standard for the diagnosis of oral conditions is the clinical examination. Despite that, it presents some disadvantages, such as the need for longer execution, higher costs due to material and specialized personnel, fatigue of the examiner, besides the increased probability of refusals to do the examination, which would reduce the response rates of the studies in which it is 
used $^{3,12-15}$. An alternative to examinations is the questionnaire applied by interviewers ${ }^{8}$, which, in contrast to the clinical examination, demands less time and resources to be performed. It does not require specialized examiners and enables the production of an expressive variety of data about the individual in only one administration ${ }^{3,12-14,16}$. Such characteristics make the use of this technique attractive for the carrying out of epidemiological studies emphasizing oral health surveillance in a broader scale $e^{4,13,16,17}$. However, it is necessary to assess the validity of oral health items included in the questionnaires applied by interviewers.

In medicine, self-report is an accepted tool to assess the occurrence of several diseases, such as juvenile rheumatoid arthritis, heart conditions, cancer, as well as risk factors, such as hypertension, physical activity, diet and smoking ${ }^{4,5}$. On the other hand, even though some studies conducted in other countries demonstrate that self-reported information on some oral conditions is valid, like number of teeth ${ }^{2,18-20}$, use of prostheses ${ }^{8,18-20}$, it is frequently questioned ${ }^{12,13}$, especially when such measures are used to diagnose periodontal conditions ${ }^{4}$. Another complicating factor is the scarce number of studies about the validity of self-reported questions for the aforementioned oral problems in different countries or social and cultural contexts ${ }^{15}$, especially for the Brazilian adult population.

A literature review concerning the validity of self-reported questions was performed and published in $2005^{4}$. However, it analyzed only studies about self-reported questions for periodontal conditions; besides that, no Brazilian studies were identified in this analysis.

The objective of this review is to describe the diagnostic validity of questions about selfreported oral conditions, especially those related to periodontal conditions, number of teeth and the use and need of prosthesis among adults, that its, the idea is to verify to what extent the questions in a questionnaire can reflect the "true" clinical oral health condition ${ }^{21}$. Besides, the objective of this study was also to present prototypes of questions about periodontal conditions, that can be submitted to validity evaluations in epidemiological surveys in the future.

\section{Methods}

A literature review was conducted through the electronic consultation of the bibliographic base Medical Literature Analysis and Retrieval System Online (MEDLINE), via PubMed. The search strategy was developed by the incorporation of MeSH terms (Medical Subject Headings), as well as free terms, selected after several attempts of search. The search in these data bases - limited from January $1^{\text {st }}, 1991$, to June 30, 2011 - was conducted with a set of terms divided into four major groups. The different terms of each group were combined using the boolean operator "OR". Group 1 gathered the terms related to validation studies ("Validation Studies" [PublicationType] OR "Reproducibility of Results" [Mesh] OR "Sensitivity and Specificity" [Mesh] OR "Sensitivity" [tiab] OR "Specificity" [tiab]); group 2 had terms related to self-reported studies, or those of screening and identification of diseases ("Self Report" [Mesh] OR "Self Assessment" [Mesh] OR "Self-assessed" [tiab] OR "Self Concept" [Mesh] OR " Self-perceived" [tiab] OR "Self-rated" [tiab] OR "Mass Screening”[ Mesh] OR "Prediction" [tiab]); group 3 had terms related to oral conditions of interest ("Oral health" [tiab] OR "Dental" [tiab] OR "Mouth" [tiab] OR "Tooth Diseases" [Mesh] OR "Dental Prosthesis" [Mesh] OR "Dentures" [Mesh] OR "Gingival Hemorrhage" [Mesh] OR "Gingivitis" [Mesh] OR "Periodontal Attachment Loss" [Mesh] OR "Periodontal Diseases” [Mesh]); finally, group 4 had terms related to studies that used questionnaires as data collection instruments ("Questionnaires" [MeSH] OR "Questionnaires" [AllFields] OR "Questionnaire" [AllFields]). These four groups were combined with the boolean operator "AND".

The first author of the review read the title and the abstract of each one of the identified articles, excluding the ineligible ones. The list obtained from this selection 
was forwarded to the third author, who did the same and excluded irrelevant studies. After reading these articles completely, the ones describing validation studies of one or more oral conditions of interest were selected. The list of references of these articles was also consulted to identify additional studies. The following inclusion criteria were adopted: (a) the subjects of the study should be adults aged between 20 - 69 years; and (b) the study should check the validity of at least one of the three oral conditions of interest, by the comparison of the answers of self-reported questions with clinical findings.

In order to extract the data from the selected articles, an electronic spread sheet was elaborated to record information regarding sample and location where the research was carried out, as well as design of the epidemiological survey (cross-sectional or cohort), how the questionnaire was applied, which was the followed guideline to execute clinical examinations, how the obtained results were recorded and analyzed, authors' conclusions, as well as the questions used and the validity analysis of each one by means of measures of sensitivity (SN), specificity (SP), positive predictive values (PPV), negative predictive values (NPV), and/or concordance rate (concordance rate between clinical findings and self-report) (CR). Considering that some articles did not present the applied questionnaire and/or the validity analysis of each question separately, we chose to send electronic messages to the authors of these studies to collect such information.

After summarizing all of the reviewed articles, four tables were constructed: one presenting the distribution of reviewed articles, according to their bibliographic characteristics, study location, investigated diseases and sample size; another one was created for each investigated disease, presenting the question and their respective minimum and maximum validity values SN, SP, PPV, NPV and/or CR. With the data of all of the questions identified for each disease, we looked for the ones that presented SN values equal to or higher than $80 \%$, and then we verified if the value of SN + SP was equal to or higher than $160 \%$, and these values were considered as acceptable ${ }^{22,23}$.

Given that the periodontal conditions represent a considerable challenge to be measured by means of self-reported questions, eight Brazilian periodontists were consulted in relation to possible questions to assess such conditions. Out of these, seven work in Brazilian institutions - three in Universidade Federal de Santa Catarina, three in Universidade Federal do Rio Grande do Sul, one in Universidade Federal do Rio de Janeiro - and another one in an institution from the USA. All of the experts were contacted individually by a standardized electronic message, which contained: a brief presentation of the authors; a description of the study; the difficulty presented by the literature to assess such conditions by self-reported questions; and questions about which would be the most important questions to ask an interviewee, in order to detect if this person presents any type of adverse periodontal condition.

The answers of each professional were firstly inserted in a table, in which there were their names and the questions they suggested. Afterwards, a table with different groups of questions was created, each one related to one specific characteristic (for instance, questions concerning bleeding gums, dental mobility, halitosis etc.). Finally, the questions of each one of these groups were compared to those found in the reviewed articles.

\section{Results}

The adopted search strategy identified 219 articles. Out of these, 200 were excluded because they did not meet the inclusion criteria. After the full reading of these 19 selected studies ${ }^{2,8,12-20,24-31}$, it was observed that 3 of them ${ }^{12,30,31}$ did not meet the inclusion criteria either. However, among the reference lists, other three eligible studies were identified ${ }^{4,32,33}$. The main characteristics of the studies are demonstrated in Table 1. Most of them were published between 2002 and 2011, and eight ${ }^{14,15,24-28,32}(42.1 \%)$ were published from 2007 to 2011. In total, the studies were conducted in 11 different countries, being 
Table 1 - Distribution of included articles, according to bibliographic characteristics, study origin, assessed oral health conditions and sample size.

Tabela 1 - Distribuição dos artigos incluídos na revisão segundo as características bibliográficas, local de estudo, agravos investigados e tamanho de amostra.

\begin{tabular}{|c|c|c|}
\hline Characteristics & $\mathrm{n}$ & $\%$ \\
\hline \multicolumn{3}{|l|}{ Period of Publication } \\
\hline $2002-2011$ & 16 & 84.2 \\
\hline $1991-2001$ & 3 & 15.8 \\
\hline \multicolumn{3}{|l|}{ Study location } \\
\hline United States & 4 & 21.1 \\
\hline Brazil & 2 & 10.5 \\
\hline Germany & 2 & 10.5 \\
\hline Israel & 2 & 10.5 \\
\hline United Kingdom & 2 & 10.5 \\
\hline Switzerland & 2 & 10.5 \\
\hline Australia & 1 & 5.3 \\
\hline India & 1 & 5.3 \\
\hline Ireland & 1 & 5.3 \\
\hline Island & 1 & 5.3 \\
\hline Japan & 1 & 5.3 \\
\hline \multicolumn{3}{|l|}{ Investigated condition } \\
\hline Periodontal and/or gum conditions & 16 & 57.1 \\
\hline Number of teeth & 7 & 25.0 \\
\hline Use and need of prostheses & 5 & 17.9 \\
\hline \multicolumn{3}{|l|}{ Sample size } \\
\hline Minimum - Maximum & $58-4.455$ & - \\
\hline Mean (standard deviation) & $631(1.135)$ & - \\
\hline Median & 246 & - \\
\hline \multicolumn{3}{|l|}{ Journals } \\
\hline Journal of Periodontology & 4 & 21.1 \\
\hline Journal of Public Health Dentistry & 3 & 15.8 \\
\hline Community Dentistry and Oral Epidemiology & 3 & 15.8 \\
\hline BMC Oral Health & 1 & 5.3 \\
\hline British Dental Journal & 1 & 5.3 \\
\hline Clinical Oral Investigations & 1 & 5.3 \\
\hline European Journal of Oral Sciences & 1 & 5.3 \\
\hline Indian Journal of Dental Research & 1 & 5.3 \\
\hline International Dental Journal & 1 & 5.3 \\
\hline Journal of Dental Research & 1 & 5.3 \\
\hline Journal of Occupational Health & 1 & 5.3 \\
\hline The New York State Dental Journal & 1 & 5.3 \\
\hline
\end{tabular}

the USA the one with more analyses; from Brazil, only two articles were found. The sample size varied significantly between studies. There was a significant proportion of articles investigating periodontal conditions (57.1\%). It is worth mentioning that the sum of investigated conditions is superior to the number of reviewed articles because the same article can analyze more than one condition simultaneously.

The questions used in the studies related to periodontal conditions, as well as SN and SP values, are presented in Table 2 . In total, 56 different questions were used in the studies. The results of the validation of these questions presented an expressive variability. SN and SP values varied, respectively, from 2 to $100 \%$, and from 18 to $100 \%$. Five of the 56 questions presented acceptable sensitivity values, according to Kingman ${ }^{22}$ and Wilson and Ashley $^{23}$ (equal or higher than $80 \%$ ): (1) "24. Gum have bled sometime"13; (2) “25. Do you believe your gums are healthy? (0) Yes, they don't bleed when tooth brushing or flossing; (1) No, I have bleeding gums when tooth brushing or flossing, (2) No, sometimes I feel taste of blood, even when not tooth brushing, (3) No, some teeth are moving and I feel pain as they move; (4) I don't know" 27; (3) "31. How do you perceive your periodontal (gum) condition on a scale from 1 (worst) to 10 (best)?"14; (4) "43. Highest recorded tooth mobility score (self-assessed)”"; (5) “44. Do you think that you can see more roots of teeth than in the past?"13,25.

Table 3 presents five different questions, with their respective results, used to identify the number of teeth that are present in different investigated populations. The minimum and maximum values found for these questions were: SN $21-91 \%$, SP $96-97 \%$ and CR $65-87 \%$. Out of the seven articles ${ }^{2,8,18-20,24,31}$ that analyzed the number of teeth, two ${ }^{18,19} \mathrm{did}$ not inform which item was used. The authors were contacted by electronic mail, however, no additional information was obtained.

Table 4 displays the three questions used to identify the use and need of prostheses. The validity results found for these questions was satisfactory, given that a $100 \%$ SN was found, besides CR ranging from 74 and $100 \%$. SP of $93.1 \%$ was also found. Similarly to what was previously described, our of the five articles ${ }^{8,18-20,23}$ that assessed this condition, two ${ }^{18,19}$ did not present the used questions. Since they were the same authors mentioned 
Table 2 - Sensitivity and specificity for self-reported questions regarding periodontal conditions.

Tabela 2 - Sensibilidade e especificidade das questões utilizadas nos estudos de validade decondições periodontais e/ou gengivais autorreferidas.

Question Results

Gum and/or periodontal disease

1. A doença gengival é um problema relativamente comum que ocorre em nossa boca. Pessoas com doença gengival devem ter sangramento ao redor dentes, gengivas inchadas, machucadas ou infeccionadas, que permanece por 2 semanas ou mais e não é causada por próteses removíveis parciais ou totais. Você acha que pode ter doença gengival? ${ }^{24}$

2. Do you think that you have gum disease? ? $^{13.25}$

3. Do you or did you have gum disease? ${ }^{17}$

$\mathrm{SN}=44.7 \% . \mathrm{SP}=76.2 \%$

4. Do you have any periodontal/gum disease? ${ }^{20}$

5. Have you ever told by dentist/dental hygienist that you have gum disease? ${ }^{13,25}$

6. Has your dentist ever told you that you had gum disease? ${ }^{17}$

7. Do you or did you have periodontitis or periodontal disease? ${ }^{17}$

8. Has your dentist ever told you that you had periodontitis or periodontal disease? ${ }^{17}$

$$
\begin{aligned}
\mathrm{SN}=17-32 \%, \mathrm{SP} & =89-93 \%^{13} \\
\mathrm{SN}=79 \%, \mathrm{SP} & =63 \%^{25}
\end{aligned}
$$

$\mathrm{SN}=37-40 \%, \mathrm{SP}=72-76 \%$

$\mathrm{SN}=17.7-19.4 \%, \mathrm{SP}=83.9-90.7 \%$

$\mathrm{SN}=15-32 \%, \mathrm{SP}=88-94 \%^{13}$

$\mathrm{SN}=67 \%, \mathrm{SP}=68 \%{ }^{25}$

$\mathrm{SN}=27-28 \%, \mathrm{SP}=80-82 \%$

$\mathrm{SN}=49-53 \%, \mathrm{SP}=64-67 \%$

$\mathrm{SN}=39-40 \%, \mathrm{SP}=72-75 \%$

Bone loss

9. Do you have periodontal disease or gum disease with bone loss? ${ }^{20}$

$\mathrm{SN}=39.3 \%, \mathrm{SP}=100.0 \%$

10. Have you ever been told by a dentist that you have periodontal/gum disease with bone loss?20

11. Algum dentista já Ihe disse que você teve perda óssea ao redor dos dentes?24

$\mathrm{SN}=32.7-50.0 \%$

$\mathrm{SP}=77.6-90.7 \%$

12. Has your dentist ever told you that you had lost bone around your teeth? ${ }^{17}$

$\mathrm{SN}=22.3 \%, \mathrm{SP}=87.4 \%$

13. Has your dentist ever shown you on a radiograph that you had lost bone around your teeth ${ }^{17}$

$\mathrm{SN}=30-33 \%, \mathrm{SP}=86-91 \%$

$\mathrm{SN}=22-26 \%, \mathrm{SP}=91-94 \%$

Scaling and root planing

14. Vocêjá fez raspagem ou alisamento radicular, algumas vezes chamado de limpeza profunda ou curetagem gengival? ${ }^{24}$

$\mathrm{SN}=22.3 \%, \mathrm{SP}=88.9 \%$

15. Usually has a scale and polish (teeth scraped) when visiting dentist ${ }^{13}$

$\mathrm{SN}=51-71 \% . \mathrm{SP}=38-49 \%$

Periodontal treatment

16. Have you ever had any form of periodontal or gum treatment? ${ }^{20}$

17. Have you ever had periodontal treatment? ${ }^{17}$

$\mathrm{SN}=48.0-52.9 \%, \mathrm{SP}=59.8-72.7 \%$

18. Have you ever been told that you need periodontal or gum treatment?20,25

$\mathrm{SN}=40-45 \%, \mathrm{SP}=76-79 \%$

$\mathrm{SN}=46.5-64.7 \%, \mathrm{SP}=64.1-77.3 \%{ }^{20}$

$\mathrm{SN}=52 \%, \mathrm{SP}=83 \% 25$

Periodontal treatment

19. Have you ever had periodontal surgery? ${ }^{25}$

$\mathrm{SN}=36 \%, \mathrm{SP}=81 \%$

20. Vocêjá se submeteu a alguma cirurgia para limpar por baixo de suas gengivas?24

$\mathrm{SN}=29.4 \%, \mathrm{SP}=81.9 \%$

21 . Aware of currently being treated for gum disease ${ }^{13}$

$\mathrm{SN}=6-17 \%, \mathrm{SP}=95-100 \%$ 
Table 2 - Continuation.

Tabela 2 - Continuação.

\begin{tabular}{ll}
\hline Question & Results
\end{tabular}

Bleeding gum

22. Have your gums bled recently? ?13,25 $^{13}$

23. Do your guns usually bleed? ${ }^{19}$

$$
\begin{gathered}
\mathrm{SN}=19-35 \%, \mathrm{SP}=86-88 \%^{13} \\
\mathrm{SN}=70 \%, \mathrm{SP}=60 \%^{25} \\
\mathrm{SN}=42.1 \%^{+}, \mathrm{SP}=76.4 \%^{+} \\
\mathrm{SN}=75-88 \%, \mathrm{SP}=18-25 \% \\
\mathrm{SN}=100 \%, \mathrm{SP}=43 \% \\
(\mathrm{Kappa}=0.81[95 \% \mathrm{Cl}=0.72-0.90])
\end{gathered}
$$

24. Gum have bled sometime ${ }^{13}$

25. Do you believe your gums are healthy? (0) Yes, they don't bleed when toothbrushing or flossing; (1) No, I have bleeding gums when toothbrushing or flossing; (2) No, sometimes I fell taste of blood, even when not toothbrushing; (3) No, some teeth are moving and I feel pain as they move; (4) I don't know ${ }^{27}$

26. How often do you have bleeding gums when brushing your teeth? ${ }^{17}$

27. How often do you have bleeding gums independent of brushing your teeth? ${ }^{17}$

Gum/periodontal condition

28. Do you think that you have gingival swelling?25

29. Do you have swollen gums? ${ }^{13,17}$

$$
\begin{gathered}
S N=43-45 \%, S P=56 \% \\
S N=31 \%, S P=70 \%
\end{gathered}
$$

30. What is your opinion regarding the health status of your gums?(0) Good; (1) $\mathrm{Bad}^{29}$

31. How do you perceive your periodontal (gum) condition on a scale from 1 (worse) to 10 (best)? ${ }^{14}$

$$
\begin{gathered}
\mathrm{SN}=52 \%, \mathrm{SP}=78 \% \\
\mathrm{SN}=9-16 \%, \mathrm{SP}=92-96 \%^{13} \\
\mathrm{SN}=45 \%, \mathrm{SP}=57-58 \%^{17} \\
\mathrm{SN}=28 \%, \mathrm{SP}=83 \%
\end{gathered}
$$

$\mathrm{SN}=84-85 \%, \mathrm{SP}=22-24 \%$ (cutoff of 5)

Periodontal pocket

32. Has any dentist/dental hygienist told you that you have deep pockets? ${ }^{19,25}$

33. Has your dentist ever told you that you had pockets? ${ }^{17}$

$\mathrm{SN}=54.5 \%^{+}, \mathrm{SP}=89.5 \%^{+19}$

$$
\mathrm{SN}=52 \%, \mathrm{SP}=75 \%^{25}
$$

Dental migration

34. Você notou nos últimos anos que seus dentes anteriores se projetaram para frente ou que surgiram espaços entre seus dentes da frente? ${ }^{24}$

35. Have you noticed that your front teeth have moved forward (towards the lip) or that gaps have developed between your front teeth? ${ }^{17}$

$\mathrm{SN}=48-52 \%, \mathrm{SP}=71-75 \%$

36. Have you ever noticed in recent years that the space between your teeth gets wider, or that 'black triangles' have developed between teeth? ${ }^{17}$

Dental migration

37. Has noticed the gaps between teeth getting bigger or food trapping between them more than in the past ${ }^{13}$

38. Thinks teeth have moved position ${ }^{13}$ $\mathrm{SN}=11.7 \%, \mathrm{SP}=82.9 \%$

$\mathrm{SN}=12-20 \%, \mathrm{SP}=95 \%$

Dental mobility

39. Vocêjá teve algum dente que se tornou bambo (amolecido) na boca por si só, sem nenhum trauma ou injúria? ${ }^{24}$

40. Are you teeth wobbly? $?^{13,25}$

41. Have you ever noticed the loosening of a single tooth? ${ }^{17}$

42. Have you ever noticed the loosening of a more than one tooth ${ }^{17}$

$\mathrm{SN}=32-46 \%, \mathrm{SP}=80-81 \%$

43. Highest recorded tooth mobility score (self-assessed) ${ }^{4}$

$\mathrm{SN}=35-52 \%, \mathrm{SP}=66-74 \%$

$\mathrm{SN}=17-39 \%, \mathrm{SP}=83-93 \%$

$$
\mathrm{SN}=17.6 \%, \mathrm{SP}=96.9 \%
$$

$\mathrm{SN}=6-32 \%, \mathrm{SP}=84-94 \%{ }^{13}$

$$
\mathrm{SN}=52 \%, \mathrm{SP}=83 \% 25
$$

$\mathrm{SN}=28-39 \%, \mathrm{SP}=89-91 \%$

$\mathrm{SN}=11-18 \%, \mathrm{SP}=98-99 \%$

$\mathrm{SN}=92 \%, \mathrm{SP}=53 \%$ 
Table 2 - Continuation.

Tabela 2 - Continuação.

\begin{tabular}{|c|c|}
\hline Question & Results \\
\hline \multicolumn{2}{|l|}{ Gum recession } \\
\hline 1. Do you think that you can see more roots of teeth than in the past? ${ }^{13,25}$ & $\begin{aligned} \mathrm{SN}=32-54 \%, \mathrm{SP} & =67-78 \%{ }^{13} \\
\mathrm{SN}=85 \%, \mathrm{SP} & =48 \%{ }^{25}\end{aligned}$ \\
\hline $\begin{array}{l}\text { 2. Have you ever noticed in recent years a recession of your gums, so that } \\
\text { teeth appear longer now? }{ }^{17}\end{array}$ & $S N=64-69 \%, S P=49-52 \%^{17}$ \\
\hline 3. Teeth hurt when eating hot, cold or sweet things ${ }^{13}$ & $\mathrm{SN}=19-53 \%, \mathrm{SP}=49-61 \%^{13}$ \\
\hline \multicolumn{2}{|l|}{ Dental loss } \\
\hline $\begin{array}{l}\text { 4. Você já teve algum dente permanente que foi perdido sozinho, sem que } \\
\text { houvesse nenhum traumatismo e sem ter ido ao dentista para fazer } \\
\text { extração? }{ }^{24}\end{array}$ & $\mathrm{SN}=24.7 \%, \mathrm{SP}=91.9 \%$ \\
\hline 5. Have you ever had a tooth extracted because of bone loss? ${ }^{17}$ & $\mathrm{SN}=2-4 \%, \mathrm{SP}=99 \%$ \\
\hline 6. Have you ever had a tooth extracted because it was loose ${ }^{17}$ & $\mathrm{SN}=18-25 \%, \mathrm{SP}=92-93 \%$ \\
\hline \multicolumn{2}{|l|}{ Dental calculus } \\
\hline 7. Has your dentist ever told you that you develop calculus easily? ${ }^{17}$ & $S N=62-73 \%, S P=47-48 \%$ \\
\hline 8. Would you say that you develop calculus easily? ${ }^{17}$ & $\mathrm{SN}=53-60 \%, \mathrm{SP}=58-59 \%$ \\
\hline \multicolumn{2}{|l|}{ Halitosis } \\
\hline $\begin{array}{l}\text { 9. Malodor or bad taste can be caused by certain food like onions or } \\
\text { garlic. Independent of the consumption of such foods, do you have } \\
\text { malodor or bad taste? } \text { ?3,17 }^{13}\end{array}$ & $\begin{array}{c}S N=29-41 \%, S P=67-71 \%^{13} \\
S N=45 \%, S P=57-58 \%^{17}\end{array}$ \\
\hline \multicolumn{2}{|l|}{ Patient profile } \\
\hline 10. Male (gender) ${ }^{13}$ & $\mathrm{SN}=30-44 \%, \mathrm{SP}=60-66 \%$ \\
\hline 11. Admits to smoking ${ }^{13}$ & $\mathrm{SN}=32-55 \%, \mathrm{SP}=32-66 \%$ \\
\hline 12. Visited a dentist less than 3 times in the last 5 years ${ }^{13}$ & $\mathrm{SN}=16-47 \%, \mathrm{SP}=71-82 \%$ \\
\hline 13. Currently taking prescribed medication ${ }^{13}$ & $\mathrm{SN}=35-48 \%, \mathrm{SP}=58-63 \%$ \\
\hline
\end{tabular}

${ }^{\dagger}$ Calculation performed from data provided in the manuscript; SN: Sensitivity; SP: Specificity.

${ }^{+}$Valor calculado a partir dos dados apresentados no artigo; SN: Sensibilidade; SP: Especificidade.

in the previous paragraph, we did not receive any responses from them.

Confidence intervals were not presented for the diagnostic validity measures for the three aforementioned conditions, because they are not presented in the original articles. Besides, all of the five articles that presented PPV and NPV for any of the questions did not present the prevalence of the disease, so they were not described in this review.

Out of the eight periodontists, five collaborated by suggesting different questions. In total, 50 possible questions have been described; they contemplated 20 different characteristics, signs or symptoms of the interviewed person, and bleeding gum, gum inflammation, halitosis, mobile teeth and dental sensitivity were the ones with more suggestions. Without considering the suggested questions that were equal or similar to the ones presented in the 19 reviewed articles ${ }^{2,4,8,13-20,29,32,33}, 19$ questions were obtained: (1) Do you see bleeding or taste blood in your mouth while tooth brushing or flossing?; (2) Do you see bleeding or taste blood in your mouth while chewing food?; (3) Do you feel your gums bleeding?; (4) Do your gums bleed spontaneously?; (5) Is there any gum growth that makes it difficult for you to close your mouth?; (6) Do you see any color change in your gum?; (7) Would you say your gum presented more redness than normal?; (8) Do you see your gum with a purple tone?; (9) Do you observe if your front teeth are opening up like a fan?; (10) Would you say your gum is going up, and therefore your teeth seem to look bigger, or are their roots showing?; (11) 
Table 3 - Sensitivity, specificity and/or percentage of agreement for self-reported questions regarding the number of remaining teeth.

Tabela 3 - Sensibilidade, especificidade e/ou percentual de concordância das questões autorreferidas utilizadas nos estudos de validade para onúmero de dentes presentes.

1. Consideramos como dentes naturais, aqueles que ainda apresentam $\mathrm{SN}=21.1 \%, \mathrm{SP}=96.4 \%$ raízes dentro do osso, mesmo que estes dentes possuam pinos, obturações, coroas, "pivôs", blocos metálicos ou sejam apoio de pontes fixas. Faça uma análise cuidadosa em sua boca e responda: quantos dentes naturais você possui? ${ }^{24}$

2. How many natural teeth do you have in your mouth now? ${ }^{20}$

SN and SP values are not presented. However, patients properly reported the number of teeth, even though there is a trend to report less teeth.

3. Have you lost any teeth or had any teeth removed?²

$$
\begin{gathered}
\mathrm{SN}=88-91 \%, \mathrm{SP}=97 \% \\
(\text { Kappa }=0.87-0.88)
\end{gathered}
$$

4. Do you still have some of your own teeth? If you do, how many teeth do you have? ${ }^{33}$

Concordance rate* Jaw: $77.1-86.7 \%($ Kappa = 0.65)

Mandible: $80-82.1 \%($ Kappa $=0.47)$ Jaw and mandible: 65.9 - 73.4\% (Kappa = 0.56)

5. Dental conditions: a) All my teeth are remaining; b) I have one or two single teeth missing and not replaced; c) I have several

Concordance rate*

Jaw: $65 \%^{\dagger}$

Mandible: $65 \%^{+}$ teeth missing and not replaced; d) All my teeth are missing, but I wear no denture. ${ }^{8}$

${ }^{\dagger}$ Calculation performed from data provided in the manuscript; *Concordance between self-assessed data and clinical examination; SN: Sensitivity; SP: Specificity.

Valor calculado a partir dos dados apresentados no artigo; *Concordância entre o autorrelato e o exame clínico; SN: Sensibilidade; SP: especificidade.

Table 4 - Sensitivity, specificity and/or percentage of agreement for self-reported questions regarding theuse and need of prostheses.

Tabela 4 - Sensibilidade, especificidade e/ou percentual de concordância das questões autorreferidas utilizadas nos estudos de validade para ouso e necessidade de prótese dentária.

Questions

1. If you have a bridge in your mouth now: How many teeth are involved with the bridge? How many missing teeth are replaced by the bridge? How many of you missing teeth: Are replaced by removable dentures? Are not replaced? $?^{20}$

2. Do you have complete or partial dentures? $?^{33}$

$$
\begin{gathered}
\text { Concordance rate* } \\
\text { Partial prosthesis } \\
\text { Jaw: } 97.8 \%^{+} \\
\text {Mandible: } 98.4 \%^{\dagger} \\
\text { Total prosthesis } \\
\text { Jaw: } 100.0 \%^{\dagger} \\
\text { Mandible: } 99.1 \%^{\dagger} \\
\text { Concordance rate* }
\end{gathered}
$$
Jaw and mandible: $73.5 \%^{\dagger}$ -supported prosthesis; c) I wear a removable partial denture; d) I wear a complete removable denture. ${ }^{8}$ 
Would you say the height of your gum has changed position, that is, has the outline of your gum around the teeth been changed?; (12) Do you feel like itching your gum?; (13) Do you want to introduce pointy objects (sticks) in your gum?; (14) Do you think that — or have you been informed about - you have tartar?; (15) Do you observe - or has been informed about - having halitosis?; (16) Have you lost teeth early in your life?; (17) Are there cases in your family of early tooth loss?; (18) In the past 12 months, did you have: 1) halitosis, bad smell or taste in your mouth; 2) loose teeth; 3 ) pain while tooth brushing; 4) wounds in your gum; 5) bleeding gum - options of answer: a) frequently; b) sometimes; c) rarely; d) never; e) edentulous; (19) Profile: gender, age, schooling, income, pregnancy, last appointment with a dentist, frequency of dentist attendance, frequency of prophylaxis (cleaning at the dentist).

\section{Discussion}

As presented in Table 2, five questions about periodontal conditions presented acceptable sensitivity values according to Kingman $^{22}$ and Wilson \& Ashley ${ }^{23}$ (equal to or higher than 80\%). However, for these questions, inadequate specificity values were observed, given that we considered as being acceptable values equal to or higher than $80 \%^{22,23}$. It is worth mentioning that such questions assessed four different characteristics of periodontal disease: (1) bleeding gum (questions 24 and 25); (2) periodontal/gum condition (question 31); (3) Dental mobility (question 43); (4) Gum recession (question $44)$, thus indicating which are the signs and symptoms of the disease reported more accurately. Even though dental mobility and gum recession are the most severe conditions of periodontal/gum disease, question 25 - about bleeding gum - was the one that presented highest sensitivity (100\%) and question $31-$ about periodontal/gum condition — was the one with highest specificity (83\%).

Considering the five questions about the number of teeth, only "Have you lost any teeth or had any teeth removed?"2 presented acceptable $\mathrm{SN}$ values. It also showed excellent SP values. With regard to the questions about the use and need of prostheses, only one (If you have a bridge in your mouth now: how many teeth are involved with the bridge? How many missing teeth are replaced by the bridge? How many of your missing teeth: Are replaced by removable dentures? Are not replaced?" ${ }^{20}$ ) presented acceptable SN and SP values.

By considering as being valid only the questions presenting the value of the sum $\mathrm{SN}+\mathrm{SP}$ equal to or higher than $160^{22,23}$, the validity is observed only for questions concerning the number of teeth and the use and need of prostheses. This means that these questions could be used so that the subject to be investigated could properly identify the number of teeth, and whether or not they use/need prostheses. For the questions about periodontal conditions, the highest value of the sum SN + SP was 145. Despite that, when the value of $\mathrm{SN}$ is equal to or higher than $80 \%$ it means that such questions could be used to screen the investigated subjects, that is, that most of the individuals with periodontal disease are identified by the question. However, if the question presents low value of specificity, it means that a high number of subjects were wrongly assessed as sick.

It is worth to mention that the validity indicators of the analyzed questions are, supposedly, context-dependent. Therefore, the maintenance of these validity indicators in contexts that are different from the original depends on a careful assessment of conceptual and semantic equivalences in the target culture, and such questions cannot be used in contexts that do not belong to the study without previous analysis ${ }^{34}$. This may be a possible explanation for finding varied sensitivity and specificity values between different studies that used the same question, as the case of questions numbers 2, 5, 18, 22, 29, 32, 40, 44 and 52, described in Table 2. This also may have occurred due to the different protocols followed by the researchers and/or the different population involved, and/or the different socioeconomic characteristics of the 
sample, and/or the different locations where the study was conducted. It is not possible to state that this is due to a single factor. The suggestion is that the results of the selfreported questions are context-dependent. They depend on the protocol followed by the researchers in order to determine the periodontal disease.

This literature review presented some limitations: (a) it used only one data base to identify the articles; (b) it limited the search from January $1^{\text {st }} 1991$ to June 302011 ; (c) there was the non-response of specific authors of the reviewed articles, as well as dental surgeons, in the attempt to contact them by electronic mail; and (d) some questions found in the review assessing the number of teeth and the use and need of prostheses indicated their results with concordance rate, instead of sensitivity and specificity, which makes it difficult to conduct a detailed analysis of their validity.

Unlike the only literature review we found about the subject ${ }^{4}$, which analyzed studies about the use of self-reported questions for periodontal conditions conducted abroad, this one also included questions about the number of teeth and the use and need of prosthesis, besides two Brazilian studies, allowing to analyze researches in the national context. Based on this review, a set of questions was selected to be evaluated in reference to the validity in a population-based study in the south of Brazil.

The findings in this review reveal there are acceptable sensitivity and specificity values to measure the number of teeth and the need of prosthesis in the form of self-reported items. This suggests that questions can be used for this purpose, and studies that rely on the reports of the interviewees can also be conducted. There is also an acceptable sensitivity rate to measure the periodontal conditions; 5 out of the 56 analyzed questions could be used in screening studies.

The development ofinstruments to measure the periodontal disease in a self-reported manner is particularly important in the field of oral health surveillance. In the USA, for instance, even though the NHANES surveys include detailed periodontal examinations, they are considered to be costly, since they demand many experienced examiners whose standardization/calibration is very difficult. Therefore, the Centers for Disease Control and Prevention (CDC) and the American Academy of Periodontology recommended, since 2003, the use of self-reported measurements that could be valid to predict the prevalence of periodontal disease and the use of population surveys as an alternative to examinations. However, there is a series of challenges to implement this proposal, since most of the suggested questions are based on the report of the dentist about the existence of periodontal disease or the awareness of the individuals about their periodontal condition. Therefore, individuals who do not see a dentist regularly do not know whether or not they have the disease, since in many cases it is asymptomatic ${ }^{35,36}$. It reinforces the indication that sensitivity and specificityvalues of self-reported measurements depend on the socioeconomic and cultural context in which individuals are inserted. Valid instruments in specific contexts are not necessarily valid in others.

A population-based Brazilian study, base line of a cohort of adults, called EpiFloria (www.epifloripa.ufsc.br), will use the oral questions presented here, which will allow the verification of the validity of such questions in the Brazilian context. Finally, we consider there is the need for further studies in the national context, in order to assess the impact of the questions about self-reported oral health conditions in epidemiological analyses. Therefore, it will be possible to empirically verify if self-reported questions can be used in such studies.

\section{Acknowledgements}

The authors would like to thank professors Dr. Cassiano Rösing(UFRGS), Dr. Mario Vettore (UFRJ), Dr. Cristiano Susin (Medical College of Georgia, EUA), Dr. Vinicus Zendron(UFSC) and Dr. Marco Aurélio Bianchini (UFSC) for collaborating, as well as all of the members of the Research Group of Odontology in Collective Health (GEOSC), of Universidade Federal de Santa Catarina, for the suggestions. 


\section{References}

1. National Center for Health Statistics. National Health Interview Survey. Hyattsville (MD); 2010.

2. Gilbert GH, Chavers LS, Shelton BJ. Comparison of two methods of estimating 48-month tooth loss incidence. J Public Health Dent 2002; 62(3): 163-9.

3. Miller K, Eke PI, Schoua-Glusberg A. Cognitive evaluation of self-report questions for surveillance of periodontitis. J Periodontol 2007; 78(7 Suppl): 1455-62.

4. Blicher B, Joshipura K, Eke P. Validation of self-reported periodontal disease: a systematic review. J Dent Res 2005; 84(10): 881-90.

5. Centers for Disease Control and Prevention. Behavioral Risk Factor Surveillance System Overview. Atlanta (GA); 2010.

6. Department of Health. South Africa Demographic and Health Survey 2003. Pretoria; 2007.

7. Brasil. Ministério da Saúde. Portal da Saúde Brasilia, DF. Diponível em: http://portal.saude.gov.br/portal/saude/ profissional/area.cfm?id_area=1521. (Acessado em $30 \mathrm{de}$ maio de 2011).

8. Palmqvist S, Söderfeldt B, Arnbjerg D. Self-assessment of dental conditions: validity of a questionnaire. Community Dent Oral Epidemiol 1991; 19(5): 249-51.

9. Ellershaw A, Spencer J. Dental attendance patterns and oral health status. Dental statistics and research series no. 57. Cat. no. DEN 208. Australian Institute of Health and Welfare. Canberra (ACT); 2011.

10. Sullivan IO, Lader D, Seymour CB, Chenery V, Fuller E, Sadler K. Foundation Report: Adult Dental Health Survey 2009. The Health and Social Care Information Centre. Leeds (WY); 2011.

11. Ministério da Saúde. PNS - Pesquisa Nacional de Saúde Brasilia, DF. Disponível em: http://www.pns.icict.fiocruz.br. (Acessado em 30 de maio de 2011).

12. Ho AW, Grossi SG, Dunford RG, Genco RJ. Reliability of a self-reported health questionnaire in a periodontal disease study. J Periodontal Res 1997; 32(8): 646-50.

13. Gilbert AD, Nuttall NM. Self-reporting of periodontal health status. Br Dent J 1999; 186(5): 241-4.

14. Levin L, Bechor R, Sandler V, Samorodnitzky-Naveh G. Association of self-perceived periodontal status with oral hygiene, probing depth and alveolar bone level among young adults. N Y State Dent J 2011; 77(1): 29-32.

15. Dietrich T, Stosch U, Dietrich D, Kaiser W, Bernimoulin JP, Joshipura K. Prediction of periodontal disease from multiple self-reported items in a German practice-based sample. J Periodontol 2007; 78(7 Suppl): 1421-8.

16. Joshipura KJ, Pitiphat W, Douglass CW. Validation of self-reported periodontal measures among health professionals. J Public Health Dent 2002; 62(2): 115-21.

17. Dietrich T, Stosch U, Dietrich D, Schamberger D, Bernimoulin JP, Joshipura K. The accuracy of individual self-reported items to determine periodontal disease history. Eur J Oral Sci 2005; 113(2): 135-40.

18. Allen F, Burke F, Jepson N. Development and evaluation of a self-report measure for identifying type and use of removable partial dentures. Int Dent J 2005; 55(1): 13-6.

19. Buhlin K, Gustafsson A, Andersson K, Håkansson J, Klinge B. Validity and limitations of self-reported periodontal health. Community Dent Oral Epidemiol 2002; 30(6): 431-7.

20. Pitiphat W, Garcia RI, Douglass CW, Joshipura KJ. Validation of self-reported oral health measures. J Public Health Dent 2002; 62(2): 122-8.

21. Fletcher RH, Fletcher SW, Wagner EH. Epidemiologia clínica: elementos essenciais. 3a ed. Porto Alegre: Artes Médicas;1996.

22. Kingman A. Statistical issues in risk models for caries. In: Baohr JD. Risk assessment in dentistry. Chapel Hill (NC): University of North Carolina Dental Ecology; 1990. p.193-200.

23. Wilson RF, Ashley FP. Identification of caries risk in schoolchildren: salivary buffering capacity and bacterial counts, sugar intake and caries experience as predictors of 2-year and 3-year caries increment. Br Dent J 1989; 167(3): 99-102.24.

24. Cyrino RM, Miranda Cota LO, Pereira Lages EJ, Bastos Lages EM, Costa FO. Evaluation of self-reported measures for prediction of periodontitis in a sample of Brazilians. J Periodontol 2011; 82(12): 1693-704.

25. Yamamoto T, Koyama R, Tamaki N, Maruyama T, Tomofuji T, Ekuni D, et al. Validity of a questionnaire for periodontitis screening of Japanese employees. J Occup Health 2009; 51(2): 137-43.

26. Nagarajan S, Pushpanjali K. Self-assessed and clinically diagnosed periodontal health status among patients visiting the outpatient department of a dental school in Bangalore, India. Indian J Dent Res 2008; 19(3): 243-6.

27. Pinelli C, Loffredo LCM. Reproducibility and validity of self-perceived oral health conditions. Clin Oral Investig 2007; 11(4): 431-7.

28. Slade GD. Interim analysis of validity of periodontitis screening questions in the Australian population. J Periodontol 2007; 78(7 Suppl): 1463-70.

29. Vered Y, Sgan-Cohen HD. Self-perceived and clinically diagnosed dental and periodontal health status among young adults and their implications for epidemiological surveys. BMC Oral Health 2003; 3(1): 3.

30. Klasser GD, de Leeuw R, Albuquerque RJ. Self-report health questionnaire: a necessary and reliable tool in dentistry. Gen Dent 2005; 53(5): 348-54.

31. Peek CW, Gilbert GH, Duncan RP, Heft MW, Henretta JC. Patterns of change in self-reported oral health among dentate adults. Med Care 1999; 37(12): 1237-48. 
32. Gilbert GH, Litaker MS. Validity of self-reported periodontal status in the Florida dental care study. J Periodontol 2007; 78(7 Suppl): 1429-38.

33. Axelsson G, Helgadóttir S. Comparison of oral health data from self-administered questionnaire and clinical examination. Community Dent Oral Epidemiol 1995; 23(6): 365-8.

34. Berry JW, Poortinga YH, Segall MH, Dasen PR. Crosscultural psychology: research and applications. New York (NY): Cambridge University Press; 2007.
35. Chattopadhyay A. Periodontal diseases. In: Chattopadhyay A. Oral Health Epidemiology. Principles and Practice. Sudbury, Massachusetts: Jones and Bartlett Publishers; 2011. p. 257-71.

36. Eke PI. Public health implications of periodontal infections in adults: conference proceedings. J Public Health Dent 2005; 65(1): 56-65.

Received on: 05/30/12

Final version presented on: 12/04/12

Accepted on: 01/15/13 